Bangladesh J. Plant Taxon. 18(1): 81-91, 2011 (June)

(C) 2011 Bangladesh Association of Plant Taxonomists

\title{
CONSERVING THREATENED PLANTS OF BANGLADESH: MILES TO GO BEFORE WE START?
}

\author{
Haseeb Md. Irfanullah ${ }^{1}$ \\ Practical Action, Bangladesh Country Office, \\ House 12/B, Road 4, Dhanmondi R/A, Dhaka 1205, Bangladesh
}

Keywords: Angiosperm; Biodiversity; Convention on Biological Diversity; Red Data Book; Red List; Vascular plants.

\begin{abstract}
In the light of important developments in biodiversity conservation in the global and national arenas over the last decade (2001-2010), this paper appraises the progress in identifying threatened vascular plant species of Bangladesh as a primary step of species diversity conservation. It is argued that, as per the IUCN Red List categories and the Volume 1 of 'Red Data Book of Vascular Plants of Bangladesh' published in 2001, only four angiosperm species are threatened (1 Critically Endangered (CR), 1 Endangered (EN), 2 Vulnerable (VU)) in Bangladesh, not 106 vascular species. This account also records that, accordingly to the 'Encyclopedia of Flora and Fauna of Bangladesh' (20072009; Volumes 5-12), 36 pteridophyte species (all VU; 18.46\% of 195 recorded species), 1 gymnosperm species (EN; $14.29 \%$ of 7 species), and 449 angiosperm species (30 CR, $126 \mathrm{EN}, 293 \mathrm{VU} ; 12.43 \%$ of 3,611 recorded species) are threatened in the country. The paper discusses and explores the importance, limitations and opportunities for red listing of threatened plants of Bangladesh. This account further advocates for a well-planned initiative to effectively complete the Red List of threatened plant species of the country by considering appropriate, established, updated assessment methods; following collaborative approach; and capitalizing on the progress made so far. Such steps may subsequently contribute to the species diversity conservation endeavours in Bangladesh.
\end{abstract}

\section{Introduction}

The year 2001 is a significant year for plant conservation in Bangladesh. This year saw the first-ever Red Data Book on threatened plant species of the country, listing out 106 vascular plant species, published by the Bangladesh National Herbarium (Khan et al., 2001). The purpose of this book was to initiate appropriate identification of threatened vascular plants of the country (pteridophytes, gymnosperms and angiosperms), so that their conservation status (IUCN Red List categories) is understood with existing conservation measures and future conservation measures can be suggested.

Since the publication of this milestone book, a number of significant events happened - globally and nationally - in the field of biodiversity conservation. Internationally, in 2002, the '2010 Biodiversity Target' was set out in the 6th Conference of Parties to the Convention of Biological Diversity (CBD COP 6) in Hague, Netherlands (CBD, 2007).

\footnotetext{
${ }^{1}$ E-mail: hmirfanullah@yahoo.co.uk
} 
In the same year, the Target was endorsed by the World Summit on Sustainable Development in Johannesburg, South Africa, and in 2005 by the UN World Summit (Countdown 2010). The year 2010 has been the 'International Year of Biodiversity' declared by the United Nations. In October of this year, the CBD COP 10 was held in Nagoya, Japan where some important decisions were taken by the Country Parties on conserving biodiversity. One of these is a revised Strategic Plan with 20 targets under five strategic goals to significantly reduce the current biodiversity loss by 2020 (CBD, 2010). The Target 12 is directly related to threatened species: "By 2020 the extinction of known threatened species has been prevented and their conservation status, particularly of those most in decline, has been improved and sustained”.

Nationally, the Government of Bangladesh prepared the 'National Biodiversity Strategy and Action Plan (NBSAP)' (MoEF, 2006) as its commitment to the CBD. The Asiatic Society of Bangladesh published 28 volumes of 'Encyclopedia of Flora and Fauna of Bangladesh', sponsored by the Ministry of Environment and Forests, Government of Bangladesh (Ahmed et al., 2008a). Early 2010 saw the publication of 'Biodiversity National Assessment and Programme of Action 2020' by the Government (MoEF, 2010) as the Fourth National Report prior to the COP 10.

In line with these important and historic events, more specifically on plant conservation in Bangladesh, a new initiative has recently been taken by the Bangladesh National Herbarium to prepare and publish the second volume of the 'Red Data Book of Vascular Plants of Bangladesh' (MoEF, 2010). Indeed, after the COP 10, focus now will increasingly be given on achieving CBD's 2020 Biodiversity Target. Completion of red listing would help us to go forward in achieving the target under species diversity conservation.

Against this backdrop, the present account highlights some important issues associated with listing of threatened plant species in 'Red Data Book of Vascular Plants of Bangladesh' (Volume 1) and 'Encyclopedia of Flora and Fauna of Bangladesh'. Attempts shall also be made to identify some vital aspects which need to be addressed to take any future endeavour to complete red listing the flora of Bangladesh, especially after the recent national and global developments. In this paper, 'Red List' and 'Red Data Book' are used interchangeably for convenience; 'red listing' refers to the whole process associated with identifying threatened species following standard assessment procedures; and 'Encyclopedia' means ‘Encyclopedia of Flora and Fauna of Bangladesh' published by the Asiatic Society of Bangladesh.

\section{Red listing at global level}

There are a number of species assessment systems in place to check out the threat status of a species. Of these, the system proposed by IUCN is the most widely accepted. A leading organisation in management of natural resources, IUCN is also a pioneer in 
developing an assessment system of global Red List of threatened species and has been continuing to do so over the last 47 years. Now, The IUCN Red List of Threatened Species $^{\mathrm{TM}}$ is a brand. The global IUCN Red List is updated on a regular basis. The latest version was released in October 2010 as '2010.4' (IUCN Red List, 2010c).

Initially, experts alone used to compile a Red List; but since 1994 appropriate conservation and environmental organizations and expert networks are involved in the assessment process through a rigorous process of data collection on certain criteria, validation of collected data, scoring, and assigning of Red List categories (IUCN Red List, 2010c). As can be seen in the Fig. 1, there are 9 or 11 categories (varies between global and regional/national assessments), but only three of these qualify as threatened categories: Critically Endangered (CR), Endangered (EN) and Vulnerable (VU). Each of these categories has its own set of criteria defining the category (IUCN, 2003; IUCN Red List, 2010a).
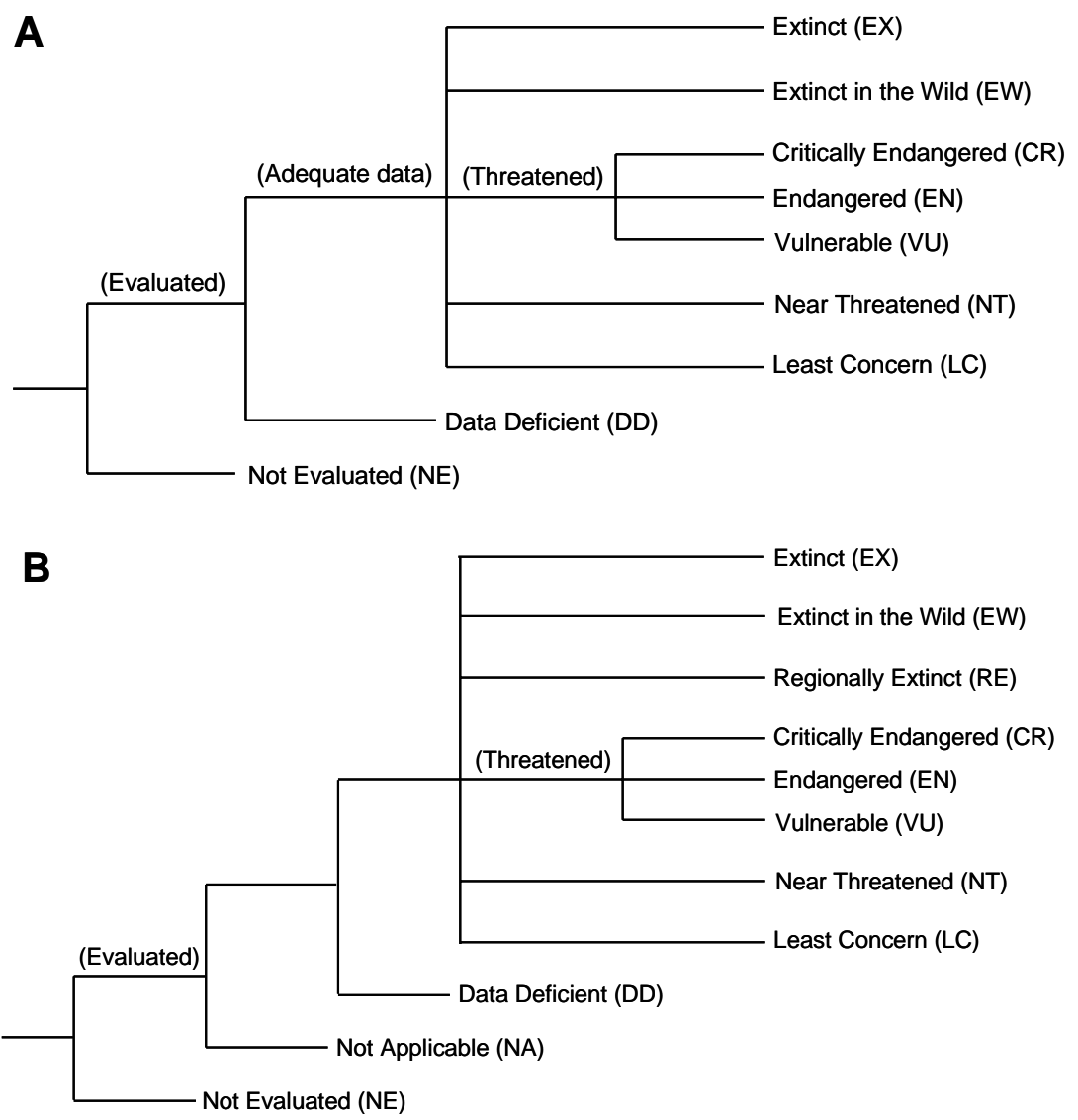

Fig. 1. IUCN Red List categories and their interrelationships, A) as per the Version 3.1 (IUCN Red List, 2010a); B) as per the guidelines for regional or national assessment (IUCN, 2003). 


\section{Red listing at national level: Bangladesh}

In addition to global species assessments, national red listing is also necessary to take conservation measures of threatened species in the national context. Therefore, the global assessment criteria need to be modified to reflect country's situation (IUCN Bangladesh, 2000; IUCN, 2003). In Bangladesh, IUCN Bangladesh set a good example of such adaptation in the late 1990's by preparing the Red Books of threatened animals of Bangladesh in five volumes covering the Red List, fish, amphibians \& reptiles, birds, and mammals. Later on, IUCN Bangladesh translated these books into Bangla in a single volume (IUCN Bangladesh, 2003).

Regarding the threatened flora, as mentioned at the beginning of this paper, Khan et al. (2001) still remains the only Red Data Book on vascular plants of Bangladesh. Some important issues associated with this book are discussed in the following sections.

\section{Red listing of flora of Bangladesh}

The issues concerning threatened plant species of Bangladesh were first presented in the early nineties (Khan, 1991; Khan et al., 2001). The published list of 12 vascular plants was based on the field experience of experts rather than following any standard quantitative or semi-quantitative methods. According to the 'IUCN Red List of Threatened Plants' of 1997, 24 plant species of Bangladesh faced various degrees of threat of extinction (IUCN, 1997, in Nishat et al., 2002).

Despite the importance of identifying threatened species in plant conservation, no concrete measures were taken by any government or non-government agencies until 1998 when a project was launched by the Bangladesh National Herbarium supported by Bangladesh Agriculture Research Council (Khan et al., 2001). IUCN Red List categories and criteria of 1994 were apparently followed to determine threatened vascular plant species. Out of 106 species listed in this book, 1 is Critically Endangered (CR), 1 Endangered (EN), 2 Vulnerable (VU), 3 Lower Risk (LR), 25 Data Deficient (DD), and 74 are Not Evaluated (NE). Almost at the same time, under the National Conservation Strategy (NCS) Implementation Project-1, an attempt was made to determine the threatened categories of plant species found in 10 different ecologically important areas/ecosystems, but it was insufficiently planned and incomplete (MoEF, 2001). Later on, Khan (2003) mentioned 95 vascular plants as threatened (92 angiosperms and three gymnosperms) without citing any references. Threatened status of plant and animal species from Bangladesh is regularly recorded in the Global IUCN Red List. For example, in the Global Red List 2006, 12 plant species were recorded as threatened; in 2010 it is 16 (IUCN Red List, 2010d).

By consulting eight volumes of 'Encyclopedia of Flora and Fauna of Bangladesh' (Volumes 5-12) on vascular plants (pteridophytes, gymnosperms and angiosperms) (Siddiqui et al., 2007a, b; Ahmed et al., 2008b, c; Ahmed et al., 2009a, b, c, d), about 
$13 \%$ species were found designated as threatened (Table 1). A few families are significantly threatened: for example, about $53 \%$ species of Orchidaceae are threatened (94 species out of 179), whereas in Lamiaceae it is more than $30 \%$ (26 species out of 86 ). Needless to say, these threatened statuses are purely in the national context. The information presented in the Encyclopedia can be considered as the most recent update for Bangladesh.

Table 1. Number of threatened species in major vascular plant groups according to the 'Encyclopedia of Flora and Fauna of Bangladesh' (Siddiqui et al., 2007a, b; Ahmed et al., 2008b, c; Ahmed et al., 2009a, b, c, d).

\begin{tabular}{lrrrrrr}
\hline $\begin{array}{l}\text { Vascular plant } \\
\text { groups }\end{array}$ & $\begin{array}{c}\text { Total no. of } \\
\text { species }\end{array}$ & $\begin{array}{c}\text { Critically } \\
\text { Endangered } \\
\text { (CR) }\end{array}$ & $\begin{array}{c}\text { Endangered } \\
\text { (EN) }\end{array}$ & $\begin{array}{c}\text { Vulnerable } \\
\text { (VU) }\end{array}$ & $\begin{array}{c}\text { Total no. of threatened } \\
\text { species (\% of total species } \\
\text { in a group) }\end{array}$ \\
\hline Pteridophytes & 195 & & 0 & 0 & 36 & $36(18.46)$ \\
Gymnosperms & 7 & & 0 & 1 & 0 & $1(14.29)$ \\
Angiosperms & 3,611 & & 30 & 126 & 293 & $449(12.43)$ \\
$\quad$ Dicotyledons & 2,623 & 8 & & 80 & 179 & $267(10.18)$ \\
$\quad$ Monocotyledons & 988 & 22 & 46 & 114 & $182(18.42)$ \\
\hline Total & $\mathbf{3 , 8 1 3}$ & & $\mathbf{3 0}$ & $\mathbf{1 2 7}$ & $\mathbf{3 2 9}$ & $\mathbf{4 8 6}(\mathbf{1 2 . 7 5})$ \\
\hline
\end{tabular}

\section{Limitations of 'Red Data Book of Vascular Plants of Bangladesh (2001)'}

Although Khan and his co-workers' endeavour of 2001 is pioneering to assess the threat on vascular plants of Bangladesh, it has a number of fundamental weaknesses limiting its use. Further, in reference to this Red Data Book, misinterpretation of the information on threatened plants of Bangladesh is widely continuing.

i) The Red Data Book does not put the threatened plants in a larger context. For example, there is no indication of how many species have so far been recorded from this country; or no attempt was made to relate the position of nationally threatened species in global context, i.e. whether they are globally threatened or not.

ii) Although it is stated that a standard format was used for data collection accompanied by extensive field visits and indication is made that IUCN Red List categories of 1994 was considered - the presented information does not comply with these.

iii) There is no comment on how many species were actually evaluated to prepare the list of 106.

iv) National adaptation of global assessment criteria is needed for any national assessment as done in IUCN Bangladesh's Red Data Book of animals (IUCN Bangladesh, 2000; IUCN, 2003). Apparently, no such adaptation was made. Moreover, no list of criteria is given which was probably used to evaluate the species. 
v) According to the standard IUCN system, only the 'Evaluated' species can be broadly classified into either 'Data Deficient' or 'Adequate Data'. The latter could successively be classified under any of the not threatened or threatened categories (CR, EN, VU) (Fig. 1). But about 70\% of the listed species in Khan et al. (2001) are categorized under Not Evaluated (NE), which is not a 'threatened' category. No explanation was given to justify this.

The editors of 'Red Data Book of Vascular Plants of Bangladesh' recognized the limitations of their endeavour (Preface, Khan et al., 2001). Nonetheless, the limitations mentioned above have never been clearly identified and clarified by any workers since then. Islam (2002) reviewed this Red Data Book and gave emphasis on the need for quantitative assessment which was missing in the book. In MoEF (2007, p. 68), designation of 74 species as Not Evaluated (NE) was mentioned as an 'interesting' step, indicating its incorrectness. All 106 plant species listed in Khan et al. (2001) are now often misquoted as 'threatened species' in many national and scientific documents (e.g. Nishat et al., 2002; MoEF, 2006; Hassan and Ahmed, 2008; MoEF, 2010). These 106 species were also indicated as the 'only' threatened plants in Bangladesh on some occasions.

\section{Clarifying some discrepancies}

This is being emphasized through this communication that, according to the Volume 1 of the 'Red Data Book of Vascular Plants of Bangladesh' (Khan et al., 2001), out of 106 plant species, only four angiosperm species are threatened in true sense, namely Corypha taliera Roxb. (Critically Endangered, CR), Aldrovanda vesiculosa L. (Endangered, EN), Knema bengalensis de Wilde and Licuala peltata Roxb. (Vulnerable, VU). The remaining 102 species designated as Lower Risk (LR, 3 species), Data Deficient (DD, 25 species) and Not Evaluated (NE, 74 species) are not threatened as these three are not threatened categories (Fig. 1).

According to the IUCN Red List category "A taxon is Not Evaluated when it has not yet been evaluated against the criteria” (Khan et al., 2001; IUCN Red List, 2010b). Fifteen species mentioned in Khan et al. (2001) as Not Evaluated (NE), namely Amomum costatum (Roxb.) Benth., Ceropegia longifolia Wall. subsp. longifolia, Cynanchum wallichii Wight, Dendrobium longicornu Wall. ex Lindl., Gymnema molle Wall. ex Wight, Hoya acuminata (Wight) Benth. ex Hook. f., H. lanceolata Wall. ex Don, Justicia oreophila C. B. Clarke, Lagenandra gomezii (Schott) Bogener \& Jacobson, Marsdenia eriocarpa Hook. f., Nothopegia acuminata J. Sinclair, Paphiopedilum insigne (Wall. ex Lindl.) Pfitz, Pentabothra nana (F. Ham. ex Wight) Hook f., Rotala simpliciuscula (S. Kurz.) Koehne and Vernonia thomsoni Hook. f., could have been classified into some other categories (e.g. threatened or Data Deficient (DD)) as these could not be found for 
the last 50-150 years since they were reported last. But those were categorised as Not Evaluated (NE).

As expected, statuses of many species as mentioned by Khan et al. (2001) are changed in the Encyclopedia (Volumes 5-12). For example, Endangered (EN) Aldrovanda vesiculosa was later evaluated as Critically Endangered (CR); Not Evaluated (NE) Dendrobium longicornu as Critically Endangered (CR); while Data Deficient (DD) Terminalia citrina (Gaertn.) Roxb. ex Fleming was evaluated as Least Concern (LC).

\section{Opportunities ahead: some reflections}

In the light of above-discussed limitations and anomalies, the following sections shed some light on the opportunities lying before us and what are the vital issues need to be considered in any future red listing initiatives in Bangladesh.

\section{Putting red listing into global and national perspectives}

While preparing a Red List or Red Data Book, the aim should not be limited to preparing or updating the List or the Book, but should be beyond that. Since the publication of Khan et al. (2001), a number of significant events happened globally and nationally pertinent to plant conservation (see Introduction of this paper). Therefore, any new initiative on Red Data Book should consider supporting, for example, the 'Bangladesh Programme of Action 2020' (MoEF, 2010) and CBD’s 2020 Biodiversity Target (CBD, 2010). The assessment process should be standard and acceptable nationally and globally. It, however, should be noted that at the moment national or regional assessments are not included on the IUCN Red List of Threatened Species, except those for endemic species (IUCN Red List, 2010b). Therefore, assessment of possible 16 endemic vascular species of Bangladesh (Hassan and Ahmed, 2008), national assessment must be fed into the global Red List.

\section{Completing and updating the Red List}

Khan et al. (2001) envisaged the need for continuous investigations to complete a Red List and regular revision of the threat status of species based upon recent, updated information. More than 12 years have past since the start of the first Red Data Book project in Bangladesh (Khan et al., 2001); therefore, updating of the information presented in the Volume 1 is needed.

In the meantime, we also have the Encyclopedia (Flora, Volumes 2-12). It has already made significant effort to identify threats to the species and to gather information on their conservation (including status, measures taken, and measures proposed). The Volumes 5-12 contain information on 3,813 vascular plant species ever recorded from the Bangladesh territory, and alarmingly identified about $13 \%$ of them as threatened (Table 1). Therefore, earnest attempts should now be made to complete the Red List of threatened plant species of Bangladesh by considering the significant information 
presented in the Encyclopedia. Focus should be given on evaluating the Not Evaluated (NE) and Data Deficient (DD) species through extensive field survey. During this process, the current threatened species status could also be re-evaluated if new information comes in, thus updating the Red List. It is particularly applicable for those species not found over the last 50-150 years since their first record (Khan et al., 2001; Hassan and Ahmed, 2008).

\section{Focusing on the assessment process}

Updated, appropriate, standard assessment scheme is the key to prepare a Red List. Khan et al. (2001) supposedly used the assessment system of IUCN proposed in 1994 (Version 2.3). But since then major changes happened in the category systems and criteria, and currently '2001 IUCN Red List Categories and Criteria' (Version 3.1) is followed (Baillie et al., 2004; IUCN Red List, 2010b). Moreover, in 2003, IUCN published guidelines on the application of the IUCN Red List criteria at national and regional levels (Fig. 1; IUCN, 2003). Hence re-evaluation of threatened vascular plants of Bangladesh is needed according to these guidelines overcoming the limitations and anomalies of Khan et al. (2001) discussed above.

Furthermore, as suggested above, if we consider the categorization of the Encyclopedia, we need to understand its strengths as well as weaknesses. Here it should be noted that in the Encyclopedia no methodology is described or referred to for determining the conservation status of a species, except that the IUCN Red List categories were used (Siddiqui et al., 2007b). From the Introduction of Encyclopedia (Ahmed et al., 2008b), it is understood that secondary information and author's experience were the key elements for categorising a species. Therefore, any future red listing attempts need to consider these issues as well.

\section{Effective collaboration}

National and international collaboration is vital in preparing any Red List. As can be seen in IUCN's Red List development, although started by IUCN in 1963, in 2000 it became an effort of 'Red List Consortium' of several organizations and networks. Since 2004, the partnership grew in a big way bringing in more expertise, thus better knowledge, information, accuracy, confidence and acceptability. Similarly, in Bangladesh, as a Government agency, the Bangladesh National Herbarium can bring together relevant bodies, like IUCN, Bangladesh Botanical Society, Bangladesh Association of Plant Taxonomists, Department of Botany of different universities and colleges, other research institutions, relevant projects \& programmes, and nonprofessional naturalists to form working group(s) for completing or updating a national Red List of plants. Expert assistance may also be sought from relevant international bodies. These will make the process much comprehensive, rigorous and acceptable, and will ensure the best use of limited resources. 


\section{Conclusion}

The title of this account posed a question if we have yet to start our threatened plant species conservation. Red List preparation is one of the first stepping stones to reach to the goal of achieving species conservation. Again, species conservation is not a stand alone effort. It is related to managing the threats putting pressure on biodiversity loss by creating awareness (in all senses and at all levels) and by putting in place effective policy and legal instruments. The current red listing process has its own challenges due to absence of complete species inventory, limited availability of information, changes in taxonomic status, biasness towards certain groups or ecosystems or regions, and difference between global and regional/national assessment processes (see IUCN Red List, 2010c). But a fresh, well-thought, well-planned, professional approach has to be taken for effective red listing of plants of Bangladesh. Only then it may effectively guide the future of plant conservation in this country.

\section{Acknowledgements}

Encouragement from Prof. M.A. Hassan, Department of Botany, University of Dhaka during the preparation of this manuscript is duly acknowledged. Comments of Dr. M. Oliur Rahman of the same department on an earlier draft are appreciated. Views expressed in this paper are the author's own and do not reflect that of Practical Action.

\section{References}

Ahmed, Z.U., Begum, Z.N.T., Hassan, M.A., Khondker, M., Kabir, S.M.H., Ahmad, M., Ahmed, A.T.A., Rahman, A.K.A. and Haque, E.U. (eds) 2008a. Encyclopedia of Flora and Fauna of Bangladesh, Vol. 1. Bangladesh Profile. Asiatic Society of Bangladesh, Dhaka, pp. 1-230.

Ahmed, Z.U., Begum, Z.N.T., Hassan, M.A., Khondker, M., Kabir, S.M.H., Ahmad, M., Ahmed, A.T.A., Rahman, A.K.A. and Haque, E.U. (eds) 2008b. Encyclopedia of Flora and Fauna of Bangladesh, Vol. 6. Angiosperms: Dicotyledons (Acanthaceae - Asteraceae). Asiatic Society of Bangladesh, Dhaka, pp. 1408.

Ahmed, Z.U., Hassan, M.A., Begum, Z.N.T., Khondker, M., Kabir, S.M.H., Ahmad, M., Ahmed, A.T.A., Rahman, A.K.A. and Haque, E.U. (eds) 2008c. Encyclopedia of Flora and Fauna of Bangladesh, Vol. 12. Angiosperms: Monocotyledons (Orchidaceae - Zingiberaceae). Asiatic Society of Bangladesh, Dhaka, pp. 1-552.

Ahmed, Z.U., Hassan, M.A., Begum, Z.N.T., Khondker, M., Kabir, S.M.H., Ahmad, M., Ahmed, A.T.A., Rahman, A.K.A. and Haque, E.U. (eds) 2009a. Encyclopedia of Flora and Fauna of Bangladesh, Vol. 7. Angiosperms: Dicotyledons (Balsaminaceae - Euphorbiaceae). Asiatic Society of Bangladesh, Dhaka, pp. 1-546.

Ahmed, Z.U., Hassan, M.A., Begum, Z.N.T., Khondker, M., Kabir, S.M.H., Ahmad, M., Ahmed, A.T.A., Rahman, A.K.A. and Haque, E.U. (eds) 2009b. Encyclopedia of Flora and Fauna of Bangladesh, Vol. 8. Angiosperms: Dicotyledons (Fabaceae - Lythraceae). Asiatic Society of Bangladesh, Dhaka, pp. 1-478. 
Ahmed, Z.U., Hassan, M.A., Begum, Z.N.T., Khondker, M., Kabir, S.M.H., Ahmad, M. and Ahmed, A.T.A. (eds) 2009c. Encyclopedia of Flora and Fauna of Bangladesh, Vol. 9. Angiosperms: Dicotyledons (Magnoliaceae - Punicaceae). Asiatic Society of Bangladesh, Dhaka, pp. 1-488.

Ahmed, Z.U., Hassan, M.A., Begum, Z.N.T., Khondker, M., Kabir, S.M.H., Ahmad, M., and Ahmed, A.T.A. (eds) 2009d. Encyclopedia of Flora and Fauna of Bangladesh, Vol. 10. Angiosperms: Dicotyledons (Ranunculaceae - Zygophyllaceae). Asiatic Society of Bangladesh, Dhaka, pp. 1-580.

Baillie, J.E.M., Hilton-Taylor, C. and Stuart, S.N. (eds) 2004. 2004 IUCN Red List of Threatened Species. A Global Species Assessment. IUCN, Gland, Switzerland and Cambridge, UK, pp. 1-191.

CBD (Convention on Biological Diversity) 2007. About the 2010 Biodiversity Target. Available from http://www.cbd.int/2010-target/about.shtml. Retrieved on 24 November 2010.

CBD (Convention on Biological Diversity) 2010. COP 10 Outcomes. <http://www.cbd.int/nagoya/ outcomes/>. Retrieved on 25 November 2010.

Countdown 2010. The 2010 Biodiversity Target. <http://www.countdown2010.net/archive/2010_target.html>. Retrieved on 24 November 2010.

Hassan, M.A. and Ahmed, A.T.A. 2008. Threat and extinction: decline and demise of species from Bangladesh. In: Ahmed, Z.U., Begum, Z.N.T., Hassan, M.A., Khondker, M., Kabir, S.M.H., Ahmad, M., Ahmed, A.T.A., Rahman, A.K.A. and Haque, E.U. (eds). Encyclopedia of Flora and Fauna of Bangladesh, Vol. 1. Bangladesh Profile. Asiatic Society of Bangladesh, Dhaka, pp. 188-201.

Islam, A.K.M. Nurul 2002. Book review on Red Data Book of Vascular Plants of Bangladesh. Bangladesh J. Plant Taxon. 9(2): 83-85.

IUCN 2003. Guidelines for Application of IUCN Red List Criteria at Regional Levels: Version 3.0. IUCN Species Survival Commission, IUCN, Gland, Switzerland and Cambridge, UK, pp. 1-26. $<$ http://www.iucnredlist.org/documents/reg_guidelines_en.pdf $>$. International Union for Conservation of Nature and Natural Resources. Retrieved on 24 November 2010.

IUCN Bangladesh 2000. Red List of Threatened Animals of Bangladesh. IUCN - The World Conservation Union, Dhaka, pp. 1-54.

IUCN Bangladesh 2003. Bangladesher Bipanno Bonno Prani (Threatened wild animals of Bangladesh). IUCN - The World Conservation Union, Dhaka, pp. 1-294. (in Bangla)

IUCN Red List 2010a. 2001 IUCN Red List Categories and Criteria version 3.1. <http://www.iucnredlist.org/technical-documents/categories-and-criteria/2001-categories-criteria>.

International Union for Conservation of Nature and Natural Resources. Retrieved on 24 November 2010.

IUCN Red List 2010b. Categories and Criteria. <http://www.iucnredlist.org/technical-documents/categoriesand-criteria>. International Union for Conservation of Nature and Natural Resources. Retrieved on 24 November 2010.

IUCN Red List 2010c. Red List Overview. <http://www.iucnredlist.org/about/red-list-overview>. International Union for Conservation of Nature and Natural Resources. Retrieved on 24 November 2010.

IUCN Red List 2010d. IUCN Red List version 2010.4: Table 5. Threatened species in each country (totals by taxonomic group). <http://www.iucnredlist.org/documents/summarystatistics/2010_4RL_Stats_

Table_5.pdf $>$. International Union for Conservation of Nature and Natural Resources. Retrieved on 25 November 2010.

Khan, M.S. 1991. Towards Sustainable Development: Conservation of Genetic Resources of Bangladesh. Ministry of Environment and Forest and National Conservation Strategy Secretariat, BARC, Dhaka, pp. 35. 
Khan, M.S. 2003. Flora. In: Islam, S., Miah, S., Ahmed, W., Chowdhury, A.M., Rahman, S.M.M., Siddiqui, K. and Kabir, S.M.H. (eds), Banglapedia: National Encyclopedia of Bangladesh. Vol. 4. Asiatic Society of Bangladesh, Dhaka, pp. 171-177.

Khan, M.S., Rahman, M.M. and Ali, M.A. (eds) 2001. Red Data Book of Vascular Plants of Bangladesh. Bangladesh National Herbarium, Dhaka, pp. 1-179.

MoEF (Ministry of Environment and Forest) 2001. Survey of Flora. National Conservation Strategy (NCS) Implementation Project-1. Ministry of Environment and Forest, Government of People's Republic of Bangladesh, Dhaka, pp. 1-384.

MoEF (Ministry of Environment and Forests) 2006. National Biodiversity Strategy and Action Plan for Bangladesh. Ministry of Environment and Forests, Government of People's Republic of Bangladesh, Dhaka, pp. 1-84.

MoEF (Ministry of Environment and Forests) 2007. Bangladesh Capacity Development Action Plan for Sustainable Environmental Governance. Ministry of Environment and Forests, Government of Bangladesh, Dhaka, pp. 1-252.

MoEF (Ministry of Environment and Forests) 2010. Biodiversity National Assessment and Programme of Action 2020. Department of Environment, Ministry of Environment and Forests, Government of Bangladesh, Dhaka, pp. 1-112.

Nishat, A., Huq, S.M.I., Barua, S.P., Reza, A.H.M.A. and Khan, A.S.M. (eds) 2002. Bio-ecological Zones of Bangladesh. IUCN Bangladesh Country Office, Dhaka, pp. 1-141.

Siddiqui, K.U., Islam, M.A., Ahmed, Z.U., Begum, Z.N.T., Hassan, M.A., Khondker, M., Rahman, M.M., Kabir, S.M.H., Ahmad, M., Ahmed, A.T.A., Rahman, A.K.A. and Haque, E.U. (eds) 2007a. Encyclopedia of Flora and Fauna of Bangladesh, Vol. 5. Bryophytes, Pteridophytes and Gymnosperms. Asiatic Society of Bangladesh, Dhaka, pp. 1-391.

Siddiqui, K.U., Islam, M.A., Ahmed, Z.U., Begum, Z.N.T., Hassan, M.A., Khondker, M., Rahman, M.M., Kabir, S.M.H., Ahmad, M., Ahmed, A.T.A., Rahman, A.K.A. and Haque, E.U. (eds) 2007b. Encyclopedia of Flora and Fauna of Bangladesh, Vol. 11. Angiosperms: Monocotyledons (Agavaceae Najadaceae). Asiatic Society of Bangladesh, Dhaka, pp. 1-399.

(Manuscript received on 27 November 2010; revised on 4 April 2011) 